\title{
Investigation of Gifted Students' Science Laboratory Academic Risk Taking Tendencies and Science Learning Orientations in Terms of Some Variables
}

\author{
Oğuzhan Nacaroğlu \\ Science and Art Center, Malatya, TURKEY \\ Oktay Kizkapan \\ Nevşehir Hacı Bektaş Veli University, Education Faculty, Nevşehir, TURKEY
}

Received: 17 January 2020 • Accepted: 6 April 2020 • Published Online: 17 April 2020

\section{Abstract}

In this research, it was aimed to investigate academic risk taking tendencies on laboratory activities and science learning orientations of gifted students. In the research (survey) quantitative research method designs was used. The sample of the research consisted of 187 gifted students who are studying in a Science and Art Center in the Eastern Anatolia Region. In the research, Science Laboratory Academic Risk Taking Scale and Learning Engagement in Science Scale were used as data collection tools. The findings indicated that the academic risk taking tendencies on laboratory activities and science learning tendencies of the gifted students were high. In addition, it was found that there was a moderate and significant relationship between the academic risk taking tendencies and their science learning orientations of gifted students.

Keywords: gifted students, laboratory activities, academic risk taking, science learning orientation, science and art center.

\section{Introduction}

In today's world, there are rapid changes in science and industry. These changes have brought some innovations in the field of education and the roles of students and teachers in educational environments have also changed (Almeida \& Simoes, 2019). In the new education systems individuals are expected to produce solutions to current problems, develop critical thinking skills, and make courageous decisions in difficult cases and exhibit behaviors such as adapting to technological developments (Kinshuk, 2016). Changes in students' needs and desires brought up the updates in education systems and in this context, the science curriculum was inevitably updated at different times.

In Turkish science curriculum, it is emphasized that students should have the skills to insist on learning, to take risks in appropriate conditions by planning and to produce evidencebased results (Ministry of National Education [MoNE], 2018). Undoubtedly, it is possible for students to acquire these competencies by creating suitable learning environments (Hassi, 2016). Laboratory activities, one of these learning environments, including processes such as trial-error

(C) Authors. Terms and conditions of Creative Commons Attribution 4.0 International (CC BY 4.0) apply. Correspondence: Oktay Kizkapan, Nevşehir Hacı Bektaş Veli University, Education Faculty, Nevşehir, TURKEY. E-mail: okizkapan@gmail.com. 
and repetition play an important role in the science teaching process (Kwok, 2015; Yazıcı \& Kurt, 2018).

- Gifted students have high academic risk taking tendency and high science learning orientations.

- There is no significant difference between academic risk taking tendencies and science learning orientations of male and female gifted students.

- Academic risk taking tendencies and science learning orientations of gifted students do not differ according to the program they are studying at science and art center.

- There is a moderate and significant relationship between academic risk taking tendencies and science learning orientations of gifted students.

Laboratory activities that make learning meaningful and permanent (Yavuz \& Akçay, 2017) increase the interest to the science course (Freedman, 1997). Students who actively take part in laboratory activities: make sense of what they learned by gaining reasoning and critical thinking skills (Atasoy, 2004), get opportunity to embody abstract knowledge, exhibit a positive attitude towards science (Freedman, 1997), and develop sophisticated epistemological beliefs on tentativeness of scientific knowledge (Kılıç \& Soran, 2011). Laboratory activities also play an important role in filling the gap between theoretical and practical applications in science teaching (Cullin, Hailu, Kupilik \& Petersen, 2017). Therefore, it cannot be expected that the science course which does not include laboratory activities will meet the mentioned general and specific aims. Also, in order to meet these aims, students need to be supported for affective qualifications as well as cognitive development in learning processes (Freedman, 1997). One of these affective characteristics is the academic risk taking tendency (ARTT) that emphasizes the courage and desire of students in their learning processes (Robinson \& Bell, 2012).

Risk taking is expressed as a desire to act against an uncertain situation (Young, 1991). Academic risk taking is expressed in different ways in the literature and it is generally defined as the willingness and courage of students to cope with the problems they face in their learning environments (Bozpolat \& Koç, 2017; Varışoğlu \& Çelikpazu, 2019; Yaman \& Köksal, 2014). Academic risk taking skills allow students to think critically and deeply on problems that do not have a definite answer and to develop their experiences (Hills, Stroup \& Wilensky, 2005; Weiner, 1994). Therefore, students with high academic risk-taking skills want to learn something new, even if there is a possibility of making mistakes, they seek alternative solutions to the problems they face (Beghetto, 2009) and they show resistance to the problems (Clifford, 1991; Gupta \& Pasrija, 2016).

ARTT, which is one of the important variables that affect students' behaviors in the classroom environment (Çetin, İlhan \& Yllmaz, 2014), can be examined under the direction of negative emotions as a result of failure, tendency to prefer difficult processes and re-recovery behaviors (Tay, Özkan \& Akyürek-Tay, 2009). Although the importance of academic risk taking skills is emphasized in the science learning process (Çakır \& Yaman, 2015; Gupta \& Pasrija, 2016), it is stated that the academic risk taking levels of students cannot be at the desired level in today's learning environments (Henriksen \& Mishra, 2013). In this context, Bozpolat and Koç (2017) emphasized that learning environments in which students can express their views freely without fear are important for cognitive development. For this reason, it is important that the teachers should know the level of academic risk taking skills of their students to be able to make the right orientation in appropriate learning environments (Avcı \& Özenir, 2016; Eugene, 2010). In the light of these evaluations, the focus of the study is on gifted students who are able to move their knowledge to changing situations, and are willing to choose difficult tasks (Coleman, Micko \& Cross, 2015) and are superior to their peers in terms of at least one qualification. 
Gifted students have important roles in the development of societies (Karakaya, Ünal, Çimen \& Yllmaz, 2018). In the future, the education of these students (Akbaş \& Çetin, 2018), who has a high potential to participate in the decision-making mechanisms of countries, should be given special importance. At the same time, the cognitive and affective dimensions should be taken into consideration in the education of these students who are shown to be the closest candidate to be the future scientist and who like to solve the problems they face by questioning (Schreglmann, 2016). It is also necessary to take the steps to increase the academic risk taking levels of these students for laboratory applications, which have a very important place in the science course. Because, considering the general and specific aims of science teaching, it is stated that science laboratory will help students in taking academic risk (Deveci, 2018). In this content, it is thought that one of the variables that affect students to take academic risk in science laboratory is science learning orientation (SLO).

Learning orientations are one of the most important variables that ensure the achievement and continuity of students' academic achievement (Sevil \& Erdoğan, 2018). Orientation to learning is a component of motivation, which is expressed as internal or external power that drives individuals to events (Yetişir \& Ceylan, 2015). The learning orientations which express the actions taken to make the learning process meaningful and valuable (Wood \& Bandura, 1989), enables students to learn from the mistakes they make and helps them cope with the problems they face. Achievement goal orientation which expresses the reasons why individuals want to learn and their beliefs in determining their goals in order to be successful (Ames, 1992), is examined in two parts as learning and performance goals (Ames \& Archer, 1988). In the goal orientation theory, the reasons and motivation levels of the students' performance in learning environments are taken into consideration (Ames, 1992) and it is thought that the students' academic learning orientations should be emphasized in this direction (Yerdelen, Aydın, Gürbüzoğlu-Yalmancı \& Göksu, 2014). In this context, in today's education system, it is aimed to increase the learning orientation levels and to provide appropriate learning orientations along with the intrinsic motivation of the students (Hırst, Knıppenberg \& Zhan, 2009).

When the literature is examined, it is seen that there are studies examining students' academic risk taking tendencies towards science (Beghetto, 2009; Çakır \& Yaman, 2015; Çınar, 2007; Daşçı \& Yaman, 2014). For example, Beghetto (2009), in his study conducted with primary school students, stated that academic risk taking behaviors of students decreased as the grade level decreased. Çakır and Yaman (2015) stated that there is a positive moderate relationship between academic risk taking skills and academic achievement of secondary school students. However, there is no study examining academic risk taking tendencies and science learning orientations of gifted students in science laboratory activities. In this respect, the study is thought to contribute to the literature. Because teaching activities carried out in order to increase academic risk taking skills and science learning orientations of gifted students in science laboratory activities are thought to help them to be willing to conduct scientific and academic studies by selecting professions appropriate to their interests and abilities, to be courageous and willing to solve the problems they face in their lives and to show leading behaviors for the scientific and technological advancement of the society. In order to take the necessary steps in this regard, it is important to examine the academic risk taking tendencies and learning orientations of gifted students in science laboratory activities.

In the literature, gender is thought as one of the variables that have an impact on students' academic risk taking tendencies and science learning orientations. It is seen that different results are reported in the literature about whether students' academic risk taking tendencies and science learning orientations differ according to gender. For example, while Clifford et al. (1990) reporting that female students' academic risk scores were lower than male students, Abdullah and Osman (2010) stated female students tend to take more risks than boys. In contrast to these studies, Strum (1971) examined the academic risk taking tendencies of 
secondary school students and concluded that there was no significant relationship between academic risk taking and gender. This result is similar to that of Miller and Byrnes (1997) and Avc1 and Özenir (2016). Therefore, inconsistencies between the results of these studies require that students' academic risk taking tendencies and science learning orientations should be examined in terms of gender variable.

Along with the gender, another important variable that can be effective on students' academic risk taking tendencies and science learning orientations is program within SAC. No study comparing academic risk taking tendencies and science learning orientations of students enrolled in different SAC programs was reached in the literature. However, it can be accepted that there is a hierarchy between SAC programs and classroom level. That is, age and class level of students increase as students go from support education to project production and management program. Therefore, the results of the studies investigating the changes in academic risk taking and science learning orientation according to grade level were examined. In this context, Açıkgül and Şahin (2019), who examined the academic risk taking tendencies of secondary school students in terms of different variables, found that the $6^{\text {th }}$ grade students "academic risk taking scores were significantly higher than the $7^{\text {th }}$ and $8^{\text {th }}$ grade students" scores. Similarly, Atkins, Leder, O'Halloran, Pollard and Taylor (1991), who conducted studies with high school students, concluded that students' academic risk taking tendencies decreased in contrast to the grade level. Beghetto (2009), on the other hand, stated that the higher the grade level, the lower the students' academic risk taking levels. Daşçı and Yaman (2014) concluded that academic risk taking behaviors of $4^{\text {th }}$ and $8^{\text {th }}$ grade students did not show significant differences. Therefore, the different results obtained in the researches require that academic risk taking and science learning orientations should be examined according to gender and program variables. In the current research, the study was conducted with gifted students studying in different programs at a SAC. SACs are an institution providing education to students who are diagnosed with special abilities in Turkey. In this educational institution, courses are offered under Support Education (SE), Recognizing Individual Capabilities (RIC), Developing Special Skill (DSS) and Project Production and Management (PPM) programs. Gifted students who succeed in certain exams are trained in these programs. In the present study, it was thought that examining academic risk taking tendencies and science learning orientations of gifted students according to gender and program variables would contribute to the literature.

In the light of all these evaluations, in this study, it is aimed to investigate the academic risk taking tendencies in laboratory activities and science learning orientations of gifted students and the relationship between these two variables. In this context, the answers to the following problems were sought:

(1) What is the level of gifted students' to take academic risk taking tendency in laboratory activities?

(2) Do the gifted students' academic risk taking tendency in laboratory activities differ by gender?

(3) Do the gifted students' academic risk taking tendency in laboratory activities differ by the program they are studying?

(4) What is the level of science learning orientation of gifted students?

(5) Do the science learning orientations of gifted students differ by gender?

(6) Do the science learning orientations of gifted students differ by the program they are studying? 
(7) Is there a significant relationship between the academic risk taking tendency and the learning orientation of science students in laboratory activities of gifted students?

\section{Method}

\subsection{Research design}

In this research, a survey design, one of the quantitative research design, was used. The survey design includes the process of collecting, organizing and describing data from the whole or a significant part of the accessible population in order to reach a generalizable judgment (King \& He, 2005). In the present study, the survey design was preferred since it was aimed to investigate the academic risk taking tendencies and science learning orientations of gifted students in science laboratory studies.

\subsection{Population and sample}

The sample of the study consisted of 187 gifted students in a SAC in Turkey. The sample of the study was selected from the accessible population using the appropriate sampling method and demographic information for the participants is presented in Table 1:

Table 1. Demographic information for participants

\begin{tabular}{cccc}
\hline Variables & Personal characteristics & f & \% \\
\hline \multirow{2}{*}{ Gender } & Girl & 97 & 51.9 \\
& Boy & 90 & 48.1 \\
\hline \multirow{2}{*}{ Age } & $8-11$ & 77 & 41.2 \\
& $12-15$ & 88 & 47.1 \\
& $16-18$ & 22 & 11.8 \\
\hline \multirow{3}{*}{ Studied SAC Program } & Support Education (SE) & 49 & 26.9 \\
& Recognizing Individual Capabilities (RIC) & 55 & 29.4 \\
& Developing Special Skills (DSS) & 53 & 28.3 \\
& Project Production and Management (PPM) & 30 & 16.0 \\
\hline
\end{tabular}

When Table 1 is examined, 97 (51.9\%) of the participants are girls and 90 (48.1\%) are boys. Among participants, 49 of them are in SE, 55 of them are in RIC, 53 of them are in DSS and 30 of them are studying in PPM program.

\subsection{Data collection tools}

The science laboratory Academic Risk Taking Scale (ARTS) was used to examine the participants' tendency to take academic risk for science laboratory studies. The necessary permissions were obtained before the scale developed by Deveci (2018) was used. The scale consists of 12 items and consists of Cautious Risk Taking, Academic Risk Taking and Unconditional Risk Taking dimensions. Sample items for each dimension are given in Table 2: 
Table 2. Dimensions and sample items of ARTS

\begin{tabular}{cccl}
\hline Scale & Dimensions & Items & \multicolumn{1}{c}{ Sample Item } \\
\hline & Cautious Risk Taking & $\begin{array}{c}1,2,3, \\
4,5\end{array}$ & $\begin{array}{l}\text { I enjoy watching my friends } \\
\text { doing dangerous experiments. }\end{array}$ \\
\cline { 2 - 4 } $\begin{array}{c}\text { Science Laboratory } \\
\text { Academic Risk Taking } \begin{array}{c}\text { Scale } \\
$\cline { 2 - 4 }\end{array}\end{array} & \begin{tabular}{c} 
Academic Risk Taking \\
\cline { 2 - 4 }
\end{tabular} & $6,7,8,9$ & $\begin{array}{l}\text { I do not avoid to try different } \\
\text { solutions while doing } \\
\text { experiments. }\end{array}$ \\
\cline { 2 - 4 } & $\begin{array}{c}\text { Unconditional Risk } \\
\text { Taking }\end{array}$ & $10,11,12$ & $\begin{array}{l}\text { I prefer to do experiments } \\
\text { alone in the lab taking risks. }\end{array}$ \\
\hline
\end{tabular}

In order to ensure the content validity of the scale, opinions of two education experts and one Turkish teacher were taken. In this context, the educational experts examined the appropriateness of the items of the scale for the gifted students, and the Turkish teacher examined the scale in terms of intelligibility, spelling and spelling rules. As a result of the evaluations, considering the intensive science laboratory studies carried out in SACs, the education experts stated that the scale could be used to examine the academic risk taking tendencies of these students for laboratory studies. Cronbach's Alpha value was calculated to ensure the reliability of the data collection tool. In this context, while Deveci (2018) calculated the reliability coefficient of the scale as .79 , it was calculated as .83 in the present study. In addition, Science Learning Orientation Scale (SLOS), which was adapted by Yetişir and Ceylan (2015), was used as data collection tool. The scale consists of 32 items and four dimensions. These dimensions are: Orientation to Learning Objectives, Self-regulation, Valuing, Self-efficacy. Sample items for each dimension are given in Table 3:

Table 3. Dimensions and sample items of SLOS

\begin{tabular}{cccc}
\hline Scale & Dimensions & Items & Sample Item \\
\hline & $\begin{array}{c}\text { Orientation to Learning } \\
\text { Objectives }\end{array}$ & $1,2,3,4,5,6,7,8$ & $\begin{array}{c}\text { It's important to } \\
\text { understand what I'm } \\
\text { working on. }\end{array}$ \\
\cline { 2 - 4 } Science Learning & Valuing & $9,10,11,12,13$, & $\begin{array}{c}\text { What I have learned has } \\
\text { practical value. }\end{array}$ \\
\cline { 2 - 4 } Orientation Scale & $14,15,16$ & $\begin{array}{c}\text { No matter how hard the } \\
\text { studies are, I can learn. }\end{array}$ \\
\cline { 2 - 4 } & Self-efficacy & $17,18,19,20,21$, \\
$22,23,24$ & $25,26,27,28,29$, & $\begin{array}{c}\text { Even if there's better things } \\
\text { to do, I keep working. }\end{array}$ \\
\cline { 2 - 4 } & Self-regulation & $30,31,32$ &
\end{tabular}

Cronbach's Alpha value was calculated to ensure the reliability of the SLOS. As a result of this study, the reliability coefficient of the scale was calculated as .84.

\subsection{Data analysis}

In the study, the lowest score that students can get from the ARTS is 12 and the highest score is 6o. On the other hand, the lowest score that can be obtained from SLOS is 32 and the highest score is 160 . In order to determine the students' academic risk taking tendencies and learning orientation levels, the cut-off points were determined by subtracting the lowest score from the highest score that can be obtained from the scale in order to make the response options continuous. In this context, the cut-off values for both scales and the corresponding levels are given in Table 4. 
Table 4. Cut-off points for the scales

\begin{tabular}{ccc}
\hline \multirow{2}{*}{ Level } & \multicolumn{2}{c}{ Cut-off Points } \\
\cline { 2 - 3 } & Academic Risk Taking Scale & Science Learning Orientation \\
Sery Low & $12.0-21.6$ & $32.0-57.6$ \\
Low & $21.6-31.2$ & $57.6-83.2$ \\
Moderate & $31.2-40.8$ & $83.2-108.8$ \\
High & $40.8-50.4$ & $108.8-134.4$ \\
Very High & $50.4-60.0$ & $134.4-160.0$ \\
\hline
\end{tabular}

In order to determine whether the students' academic risk taking tendencies and science learning orientation scores differed by gender t-test was used, and ANOVA was used to determine whether they differed by the program. In order to perform ANOVA and t-test analyzes, firstly, the descriptive statistical analysis was done to check whether the data showed normal distribution within the groups. Finally, correlation analysis was conducted in order to determine whether there is a significant relationship between students' academic risk taking tendencies and science learning orientations. In this context, Pearson Product Moment Correlation Coefficient analysis, which is used to determine whether there is correlation between normal distributed variables and direction of determined correlation, is used.

\section{Results}

In this study, firstly, the findings obtained from descriptive statistical analysis are presented. In this context, it was checked by normality test whether the students' academic risk taking and science learning orientation scores were distributed normally. In normality tests, Kolmogorov-Smirnov test is suggested if the sample consists of 35 or more participants (McKillup, 2012). Since there are 187 participants in the study, Kolmogorov-Smirnov normality test was performed and the results are given in Table 5 .

Table 5. Normality test results

\begin{tabular}{|c|c|c|c|c|c|}
\hline \multirow{2}{*}{ Scales } & \multirow{2}{*}{\multicolumn{2}{|c|}{ Variables }} & \multicolumn{3}{|c|}{ Kolmogorov-Smirnov } \\
\hline & & & Statistics & df & Sig. \\
\hline \multirow{6}{*}{$\begin{array}{c}\text { Academic Risk } \\
\text { Taking }\end{array}$} & \multirow{2}{*}{ Gender } & Boy & .078 & 90 & .200 \\
\hline & & Girl & .059 & 97 & .200 \\
\hline & \multirow{4}{*}{ Program } & SE & .089 & 49 & .200 \\
\hline & & RIC & .080 & 55 & .200 \\
\hline & & DSS & .117 & 53 & .067 \\
\hline & & PPM & .094 & 30 & .200 \\
\hline \multirow{6}{*}{$\begin{array}{c}\text { Science Learning } \\
\text { Orientation }\end{array}$} & \multirow{2}{*}{ Gender } & Boy & .068 & 90 & .200 \\
\hline & & Girl & .078 & 97 & .174 \\
\hline & \multirow{4}{*}{ Program } & SE & .134 & 49 & .028 \\
\hline & & RIC & .070 & 55 & .200 \\
\hline & & DSS & .060 & 53 & .200 \\
\hline & & PPM & .114 & 30 & .200 \\
\hline
\end{tabular}

As can be seen in Table 5, students' academic risk taking tendencies and science learning orientation scores show a normal distribution by gender ( $\mathrm{p}>.05)$. Therefore, t-test can be used when comparing students' scores according to gender. On the other hand, it was seen that the normality assumption in the SE group was not met $(\mathrm{p}<.05)$, but not for the other programs ( $p>$.05). After the scores of the students registered in the SE program were found to be significant, the mean, mode and median values and kurtosis and skewness values of these students' scores were examined. The mean (44.92), mode (45.00) and median (45.00) values of students were very close to each other. In addition, the kurtosis (.524) and skewness (.328) values of the scores do 
not exceed the range of $+1 /-1$. Therefore, it was assumed that the scores were normally distributed within this group (Fraenkel \& Wallen, 2006; George \& Mallery; 2001). Based on these results, it was decided that ANOVA could be used to determine whether the scores differ according to the group variable.

From the findings of normality assumption, the findings about the level of students' academic risk taking tendencies and science learning orientations were examined. The mean scores of the students were evaluated according to the criteria defined in Table 4 . The results obtained are given in Table 6.

Table 6. Average values of students from the scales

\begin{tabular}{lc}
\hline Scale & Mean \\
\hline Academic Risk Taking Tendency & 45.21 \\
\hline Science Learning Orientation & 123.94 \\
\hline
\end{tabular}

In Table 4, it is stated that the average of the scores from the scales is accepted as "High" if it is in the range of 40.8-50.4 for the academic risk taking tendency scale and in the 108.8-134.4 range for the science learning orientation scale. In this context, when the values in Table 6 are compared with the determined limit values, it can be said that students' academic risk taking tendencies and science learning orientations are "high".

After determining the levels of the students, the analysis was conducted to determine whether the scores obtained from the scales differ by gender. The t-test was used to compare scores according to gender. The obtained results are given in Table 7.

Table 7. Comparison results of ARTT and science learning orientation scores by gender

\begin{tabular}{|c|c|c|c|c|c|c|}
\hline & \multicolumn{2}{|c|}{$\begin{array}{c}\text { Levene Test on Equality } \\
\text { of Variances }\end{array}$} & \multicolumn{3}{|c|}{ t-test } \\
\hline & & $\mathrm{F}$ & p. & $\mathrm{t}$ & $\mathrm{SD}$ & p. \\
\hline \multirow{2}{*}{$\begin{array}{l}\text { Academik } \\
\text { Risk Taking } \\
\text { Tendency }\end{array}$} & \multirow{2}{*}{$\begin{array}{l}\text { Equal Variances Assumed } \\
\text { Equal Variances Not } \\
\text { Assumed }\end{array}$} & .475 & .491 & -.036 & 185 & .971 \\
\hline & & & & -.036 & 179.92 & .971 \\
\hline Science & Equal Variances Assumed & .228 & .633 & .874 & 185 & .383 \\
\hline $\begin{array}{l}\text { Learning } \\
\text { Orientation } \\
\end{array}$ & $\begin{array}{l}\text { Equal Variances Not } \\
\text { Assumed }\end{array}$ & & & .873 & 183.34 & .384 \\
\hline
\end{tabular}

When Table 7 is examined, it is seen that the assumption of equality of variances is not violated for both scales ( $\mathrm{p}>$.05). Therefore, the significance values in the case where the variances are equal are considered in the table. Since the t-test results for both scales are not significant, it can be said that there is no significant difference between the ARTT ( $p>.05, t=-.036)$ and science learning orientations $(\mathrm{p}>.05, \mathrm{t}=.874)$ of gifted female and male students. In other words, the tendency of gifted students to take academic risk and science learning orientation does not change according to gender.

After determining whether the scores obtained from the scales did not differ according to gender, it was examined whether the scores of the students differed by the program they were studying. Since there are four different program types in SAC, ANOVA was used to compare the scores. As a result of the analysis, information on the assumption of equality of variances is given in Table 8 and ANOVA results are given in Table 9. 
Table 8. Levene test results for ARTT and SLO scores

\begin{tabular}{lcccc}
\hline & Levene Statistics & SD1 & SD2 & p. \\
\hline Academic Risk Taking Tendency & .896 & 3 & 183 & .444 \\
Science Learning Orientation & .994 & 3 & 183 & .397 \\
\hline
\end{tabular}

As can be seen in Table 8, the assumption of equality of variances in both scales was not violated ( $\mathrm{p}>$.05). After checking this assumption, ANOVA was carried out and the results are given in Table 9.

Table 9. ANOVA results for ARTT and SLO scores

\begin{tabular}{llccccc}
\hline & & $\begin{array}{c}\text { Sum of } \\
\text { Squares }\end{array}$ & SD & Mean Square & F & p. \\
\hline \multirow{2}{*}{ Academic Risk } & Between Groups & 64.008 & 3 & 21.336 & .839 & .474 \\
Taking Tendency & Within Group & 4655.435 & 183 & 25.440 & & \\
& Total & 4719.444 & 186 & & & \\
\hline \multirow{2}{*}{ Science Learning } & Between Groups & 656.282 & 3 & 218.761 & 1.186 & .317 \\
Orientation & Within Group & 33762.071 & 183 & 184.492 & & \\
& Total & 34418.353 & 186 & & & \\
\hline
\end{tabular}

When Table 9 is examined, it can be said that academic risk taking tendencies and science learning orientations of gifted students do not differ according to the program variable (for Academic Risk Taking Tendency $[\mathrm{F}(3-183)=.839 ; \mathrm{p}=.474>.05]$, for Science Learning Orientation $[\mathrm{F}(3-183)=1.186 ; \mathrm{p}=.317>.05]$.

After comparing student scores according to the program studied at SAC, it was examined whether there was a significant relationship between academic risk taking tendencies and science learning orientations of gifted students. In order to determine the relationship between variables, Pearson Product-Moment Correlation Coefficient analysis was performed and the results are given in Table 10.

Table 10. The results of the relationship between ARTT and SLO

\begin{tabular}{llcc}
\hline & & $\begin{array}{c}\text { Academic Risk } \\
\text { Taking Tendency }\end{array}$ & $\begin{array}{c}\text { Science Learning } \\
\text { Orientation }\end{array}$ \\
\hline Academic Risk Taking & Pearson Correlations & 1 & $.430^{* *}$ \\
Tendency & $\mathrm{p}$. & & .000 \\
& $\mathrm{~N}$ & 187 & 187 \\
\hline Science Learning Orientation & Pearson Correlations & $.430^{* *}$ & 1 \\
& $\mathrm{p}$. & .000 & 187 \\
& $\mathrm{~N}$ & 187 & \\
\hline
\end{tabular}

** Correlation is significant at 0.01 (2-Way) level.

If the correlation coefficient between the two variables is between .10 and .29, it refers to low correlation, if correlation coefficient is between .30 an.49, it means the correlation is moderate and if the coefficient is between .50 and 1.00, then the two variables are highly correlated (Cohen, 1988). Therefore, as it can be seen in Table 10, it can be said that there is a moderate and significant correlation in a positive way between the academic risk taking tendencies of gifted students and their science learning orientations $(\mathrm{p}<.05, \mathrm{r}=.430)$.

\section{Discussion}

In this research, it was aimed to investigate academic risk taking tendencies and science learning orientations of gifted students in laboratory activities. In this context, 187 gifted students who were studying at a SAC in Turkey participated to the study. When the findings 
obtained were examined, it was concluded that the gifted students had high academic risk taking tendencies in the laboratory activities (Table 6). This result is similar to some studies (Akdağ, Köksal \& Ertekin, 2017; Akkaya, 2016; Tay, Özkan \& Tay, 2009). The high academic risk-taking tendencies of gifted students may be the result of their education which aims to develop skills such as solving problems by questioning (Schreglmann, 2016), transferring knowledge to changing situations and showing a tendency to choose compelling tasks (Coleman, Micko \& Cross, 2015). Because gifted students actively participate in laboratory applications and projects at science and art centers besides their normal education (Barış, 2019; MoNE, 2016). It can be concluded that these practices and activities aimed at solving actual problems provide high levels of academic risk-taking for laboratory studies of gifted students. In support of this result, Tay, Özkan and Tay, (2009) stated that there is a positive relationship between problem solving skills and academic risk taking tendencies of gifted students.

Similarly, gifted students have a high science learning orientation (Table 6). In the process of examining science learning orientations, it is emphasized that self-efficacy, selfregulation skills, valuation and achievement goal orientations are important and these dimensions are indispensable elements in science teaching (Yetişir \& Ceylan, 2015). It is stated in the literature that if the students value the course, they demonstrate the skills to organize the learning in line with certain goals and exhibit the necessary desire and courage in the subject, their orientation towards the course and academic achievement will be high (Arslan, 2011; İsrael, 2007; Sevil \& Erdoğan, 2018). Therefore, it is expected that gifted students have high science learning orientations.

Regarding the gender variable, it was found that there is no significant difference between academic risk taking tendencies of male and female gifted students for laboratory activities (Table 7). This result is different from some studies (Clifford, Chou, Mao, Lan \& Kuo, 1990) examining students' tendency to take academic risk but shows similarity with some other studies (Chou, 1992; Strum, 1971). These results reveal the inconsistency of whether students' academic risk taking tendencies show a significant difference in terms of gender. Therefore, it is important to carry out more studies on this issue. Similarly, there is no significant difference between the science learning orientations of male and female gifted students (Table 7). This is desirable in terms of gender equality. Therefore, it can be concluded that the intrinsic motivations, self-efficacy and self-regulation skills of male and female participants are similar. In the literature, while some studies reached similar results with the current research (İrven \& Şenler, 2017; Kanat \& Kozikoğlu, 2018; Kıran \& Sungur, 2012), there are also other studies that reach different results (Anderman \& Young, 1994; Britner \& Pajares, 2006). Therefore, this inconsistency in the literature reveals the importance of further studies on this issue.

It was determined that the academic risk taking tendencies of the gifted students did not differ in terms of the program studied. This result shows that the students' academic risk taking level does not change as they move to higher education program and it differs with some studies in the literature (Beghetto, 2009; Byrnes, Miller \& Schafer, 1999; Daşcı \& Yaman, 2014). For example, Daşcı and Yaman (2014) examined the students' tendency to take academic risk in science course according to Piaget's cognitive development period and stated that the students studying at lower grades had higher academic risk taking levels compared to the students studying at higher grades. Researchers also stated that students' academic achievement can be increased by developing academic risk taking behaviors from young ages. Beghetto (2009), on the other hand, emphasized that academic risk taking behaviors increase as the grade level increase. These results indicate that there is no cetain relationship between program studied at SACS and academic risk taking behaviors. Nevertheless, it can be concluded that the main reason why the academic risk taking levels of the students for laboratory studies did not differ by the program variable is because similar learning environments including experimental practices, laboratory activities and projects, which enable students to take an active part in each program applied in 
SACs. However, in order to obtain a clearer result, it is important to conduct studies examining the academic risk taking tendencies of different groups of students towards laboratory activities. Likewise, it was seen that the participants' science learning orientations did not differ in terms of the program they studied (Table 9). According to this result, it can be concluded that the science courses conducted at each program provide the students' inner motivation, self-efficacy and selfregulation skills.

\section{Conclusion}

It is determined that there is a moderate and significant relationship between academic risk taking tendencies and science learning orientations of gifted students (Table 10). According to these results, it can be concluded that high levels of academic risk taking tendencies are associated with higher levels of science learning orientations. Therefore, it is thought that the setting learning environments that will enable students to take academic risks in laboratory activities will make their learning meaningful and valuable (Wood \& Bandura, 1989). Besides, it is emphasized that academic achievement of students with high science learning orientations will be continuous (Sevil \& Erdoğan, 2018). In the light of all these assessments, it is important to create learning environments where students can take academic risks for the gifted students who have the potential to play important roles in the development of societies (Karakaya et al., 2018).

The following recommendations were made within the framework of the results of the research: In order to increase the academic risk taking skills of the gifted students in laboratory studies, projects and experimental practices should be given more attention in both schools and SACs.

The findings of this study are limited with the data collected from 187 gifted students who are studying at a SAC in Turkey. By extending the scope of the study, more reliable results can be obtained.

Quantitative research method was used in the study. It is important to investigate students' academic risk taking tendencies with in-depth research using qualitative research methods.

\section{Acknowledgements}

This research did not receive any specific grant from funding agencies in the public commercial, or not-for-profit sectors.

The authors declare no competing interests. 


\section{References}

Abdullah, M., \& Osman, K. (2010). 21 ${ }^{\text {st }}$ century inventive thinking skills among primary students in Malaysia and Brunei. Procedia - Social and Behavioral Sciences, 9, 1646-1651.

Açlkgül, K., \& Şahin, K. (2019). Investigation of secondary school students' perceptions on their mathematics-oriented academic risk taking behaviors in terms of gender, grade level, metacognition and attitude variables. Adiyaman University Journal of Social Sciences, 32, 130.

Akbaş, M., \& Çetin, P. S. (2018). The investigation of gifted students' argumentation level and informal reasoning related to socioscientific issues. Necatibey Faculty of Education Electronic Journal of Science and Mathematics Education, 12(1), 339-360.

Akdă̆, E. M., Köksal, M. S., \& Ertekin, P. (2017). Investigating gifted middle school students' intellectual risk taking behaviors in learning science across gender and grade, Adnan Menderes University Journal of Social Sciences Institute, 4(2), 16-25.

Akkaya, G. (2016). The effect of animations involving models on fourth grade gifted students' intellectual risk taking and learning in science courses. Unpublished Doctoral Dissertation. İnönü University, Institute of Educational Sciences, Malatya.

Almeida, F., \& Simoes, J. (2019). The role of serious games, gamification and industry 4.0 tools in the education 4.0 paradigm. Contemporary Educational Technology, 1O(2), 120-136.

Ames, C. (1992). Classrooms goals structures and student motivation. Journal of Educational Psychology, 84, 261-271.

Ames, C., \& Archer, J. (1988). Achievement goals in the classroom students' learning strategies and motivation processes. Journal of Educational Psychology, 80, 260-267.

Anderman, E. M., \& Young, A. L. (1994). Motivation and strategy use in science: Individual differences and classroom effects. Journal of Research in Science Teaching, 31(8), 811-831.

Arslan, A. (2011). Examining the achievement goal orientations and constructivist approach opinion of preservice teachers. Ondokuz Mayis University Journal of Education Faculty, 3o(1), 107-122.

Atasoy, B. (2004). Science learning and teaching. Ankara: Asil publishing, 147.

Atkins, W. J., Leder, G. C., O’Halloran, P. J., Pollard, G. H., \& Taylor, P. (1991). Measuring risk taking. Educational Studies in Mathematics, 32, $297-308$

Avcı, E., \& Özenir, Ö. S. (2016). Investigation of maths oriented academic risk-taking behaviours of secondary school students by some variables. Turkish Journal of Computer and Mathematics Education, 7(2), 304-320.

Barış, N. (2019). Investıgatıng science and maths teachers' stem education practices at BILSEM. Unpublished Master Thesis Tezi. Hacettepe University, Institute of Educational Sciences, Ankara.

Beghetto, R. A. (2009). Correlates of intellectual risk taking in elementary school science. Journal of Research in Science Teaching, 46(2), 210-223.

Bozpolat, E., \& Koç, H. (2017). Study on the mathematics-oriented risk-taking behaviors of $8^{\text {th }}$ grade students in view of certain variables. Hacettepe University Journal of Education, 32(3), 525543.

Britner, S. L., \& Pajares, F. (2006). Sources of science self-efficacy beliefs of middle school students. Journal of Research in Science Teaching, 43(5), 485-499.

Byrnes, J. P., Miller, D., \& Schafer, W. (1999). Gender differences in risk taking: A meta-analysis. Psychological Bulletin, 125, 367-383. 
Chou, F. C. (1992). Academic risk-taking as a function of evaluation assessment ratio and payoff increments. UMI Pro Quest Digital Dissertations.

Clifford, M. M. (1991). Risk taking, theoretical, empirical, and educational considerations. Educational Psychologist, 26(3\&4), 263-297.

Clifford, M. M., Chou, F. C., Mao, K-N, Lan, W. Y., \& Kuo, S-Y. (1990). Academic risk taking, development, and external constraint. Journal of Experimental Education, 59, 45-66.

Cohen, J. (1988). Statistical power analysis for the behavioral sciences ( $2^{\text {nd }}$ Ed.). Hillsdale, NJ: Lawrence Erlbaum Associates, Publishers.

Coleman, L. J., Micko, K. J., \& Cross, T. L. (2015). Twenty-five years of research on the lived experience of being gifted in school: Capturing the students' voices. Journal for the Education of the Gifted, $38(4), 358-376$.

Cullin, M., Hailu, G., Kupilik, M., \& Petersen, T. (2017). The effect of an open-ended design experience on student achievement in an engineering laboratory course. International Journal of Engineering Pedagogy, 7(4), 102-116.

Çakır, E., \& Yaman, S. (2015). The relationship between students' intellectual risk-taking skills with metacognitive awareness and academic achievement. Gazi Journal of Education Sciences, 1(2), $163-178$.

Çetin, B., İlhan, M., \& Yılmaz, F. (2014). An investigation of the relationship between the fear of receiving negative criticism and of taking academic risk through canonical correlation analysis. Educational Sciences: Theory \& Practice, 14(1), 135-158.

Çınar, D. (2007). The effects of the problem based learning approach on the higher level thinking skills and levels of academic risk taking in primary science education. Unpublished Master Thesis Tezi. Selçuk University, Institute of Educational Sciences, Konya.

Daşçı, A. D., \& Yaman, S. (2014). Investigation of intellectual risk-taking abilities of students according to Piaget's stages of cognitive development and education grade. Journal of Theoretical Educational Science, 7(3), 271-285.

Deveci, İ. (2018). Middle school science laboratory academic risk taking scale: Validity and reliability study. Elementary Education Online, 17(4), 1861-1876

Eugene, O. (2010). Scientific risk-taking by young students fades with age. https://uonews.uoregon.edu /archive/news-release/2010/4/scientific-risk-taking-young students-fades-age.

Fraenkel, J. K., \& Wallen, N. E. (2006). How to design and evaluate research in education (6 $6^{\text {th }}$ Ed). New York: McGraw-Hill, Inc.

Freedman, M. P. (1997). Relationship among laboratory instruction, attitude toward science, and achievement in science knowledge. Journal of Research in Scrence Teaching, 34(4), 343-357.

George, D., \& Mallery, P. (2001). SPSS for Windows. Step by step (third edition). USA: Allyn \& Bacon.

Gupta, M., \& Pasrija, P. (2016). Problem solving ability \& locality as the influential factors of academic achievement among high school students. Issues and Ideas in Education, 4(1), 37-50.

Hassi, A. (2016). Effectiveness of early entrepreneurship education at the primary school level: Evidence from a field research in Morocco. Citizenship, Social and Economics Education, 15(2), 83-103.

Henriksen, D., \& Mishra, P. (2013). Learning from creative teachers. Educational Leadership, 7o(5). http://www.ascd.org/publications/educational-leadership/feb13/vol70/numo5/Learningfrom-Creative-Teachers.aspx

Hills, T., Stroup, W., \& Wilensky, U. (2005). Patterns of risk seeking and aversion among preservice teachers: Mathematical decisions, preference, efficacy, and participation. Paper presented at the Annual Meeting of the American Educational Research Association, Montreal, April. 
Hirst, G., Van Knippenberg, D., \& Zhou, J. (2009). A cross-level perspective on employee creativity: Goal orientation, team learning behavior, and individual creativity. Academy of management journal, 52(2), 280-293.

İrven, Ö., \& Şenler, B. (2017). Motivational beliefs and self-regulation skills of $4^{\text {th }}$ grade students in science. Trakya University Journal of Social Sciences, 19(2), 367-379.

İsrael, E. (2007). Self-regulation instruction, science achievement and self-efficacy. Unpublished Doctoral dissertation, Dokuz Eylül University, Institute of Educational Sciences, İzmir.

Kanat, F., \& Kozikoğlu, İ. (2018). $8^{\text {th }}$ grade secondary school students' self-regulation strategies, motivational beliefs and attitudes towards learning English. The Journal of Erzincan University Education Faculty, 20(3), 725-748.

Karakaya, F., Ünal, A., Çimen, O., \& Yılmaz, M. (2018). Investigation of environmental perceptions of gifted students and their peers. Online Science Education Journal, 3(1), 25-32.

Kılıç, D. S., \& Soran, H. (2011). Behavioral intention questionnaire for biology laboratory applications. Paper Presented at $2^{\text {nd }}$ International Conference on New Trends in Education and Their Implications, Antalya.

Kıran, D., \& Sungur, S. (2012). Middle school students' science self-efficacy and its sources: Examination of gender difference. Journal of Science Education and Technology, 21, 619-630.

King, W. R., \& He, J. (2005). Understanding the role and methods of meta-analysis in IS research. Communications of the Association for Information Systems, 16, 665-686.

Kinshuk (2016). Designing adaptive and personalized learning environments (Interdisciplinary approaches to educational technology). Arbingdon, UK: Routledge.

Kwok, P. W. (2015). Science laboratory learning environments in junior secondary schools. Asia-Pacific Forum on Science Learning and Teaching, 16(1), 1-28.

McKillup, S. (2012). Statistics explained: An introductory guide for life scientists (Second edition). United States: Cambridge University Press.

Ministry of National Education [MoNE] (2016b). Science and Art Center Guidelines. Ankara: Ministry of National Education.

Ministry of National Education [MoNE] (2018). Science course curriculum (Primary and secondary school 3, 4, 5, 6, 7 and 8 Grades). Ankara: Board of Education and Training.

Miller, D. C. \& Byrnes, J. P. (1997). The role of contextual and personal factors in children's risk taking. Development Psychology, 33(5), 814-823

Mun, Y. Y., \& Hwang, Y. (2003). Predicting the use of web-based information systems: self-efficacy, enjoyment, learning goal orientation, and the technology acceptance model. International journal of human-computer studies, 59(4), 431-449.

Robinson, L. E., \& Bell, A. (2012). Exploring adult risk propensity and academic risk-taking within the online learning environment. Paper presented at the Adult Education Research Conference (AERC) (pp. 258-264). Saratoga Springs.

Schreglmann, S. (2016). Content analysis of higher education thesis made about gifted students in Turkey (2010-2015). Journal of Gifted Education Research, 4(1), 14-26.

Sevil, H. H. S., \& Erdoğan, D. G. (2018). Investigation of middle school students' motivation towards science learning in terms of some variables. Journal of Multidisciplinary Studies in Education, 1(1), 36-46.

Strum, I. S. (1971). The relationship of creativity and academic risk-taking among fifth graders: Final report. ERIC Document Reproduction Service No: ED046212.

Tay, B., Özkan, D., \& Akyürek-Tay, B. (2009). The effect of academic risk taking levels on the problem solving ability of gifted students. Procedia Social and Behavioral Sciences, 1(1), 1099-1104. 
Varışoğlu, B., \& Çelikpazu, E. E. (2019). Secondary school students' academic risk-taking levels in Turkish lesson. International Journal of Progressive Education, 15(4), 241-258.

Weiner, B. (1994). Integrating social and personal theories of achievement striving. Review of Educational Research, 64(4), 557-573.

Wood, R., \& Bandura, A. (1989). Impact of conceptions of ability on self-regulatory mechanisms and complex decision making. Journal of personality and social psychology, 56(3), 407.

Yaman, S., \& Köksal, M. S. (2014). Adaptation of the Turkish form of perception scale for mental risk taking and predictors in science learning: Validity and reliability study. Journal of Turkish Science Education, 11(3), 119-142.

Yavuz, S., \& Akçay, M. (2017). The investigation of the effects of computer-assisted instruction and laboratory instruction on students' achievement and students' attitudes towards the course. Karaelmas Journal of Educational Sciences, 5(1), 39-48.

Yazıcı, M., \& Kurt, A. (2018). Investigation of the effect of using the laboratory in secondary school science teaching to the academic achievements of the students in line with the opinions of teachers and students. Journal of Bayburt Education Faculty, 13(25), 295-320.

Yerdelen, S., Aydın, S., Gürbüzoğlu-Yalmancı, S., \& Göksu, V. (2014). Relationship between high school students' achievement goal orientation and academic motivation for learning biology: A path analysis. Education and Science, 39, 437-446.

Yetişir, M. I., \& Ceylan, E. (2015). The adaptation of students' adaptive learning engagement in science scale into Turkish. Elementary Education Online, 14(2), 657-670.

Young, R. D. (1991). Risk-taking in learning, K-3. NEA Early Childhood Education Series. National Education Association Professional Library, PO Box 509, West Haven, CT 06516. 
O. Nacaroğlu \& O. Kizkapan - Investigation of Gifted Students' Science Laboratory...

C O A $\mathrm{s}$ 